\title{
HYBRIDISM IN THE EASTERN AND MOUNTAIN BLUEBIRDS
}

\author{
by John Lane, 1701 Lorne Avenue, Brandon, Manitoba
}

On May 14, 1967, a field party from the Brandon Junior Birders Club was checking nest-boxes in an area running through the towns of Oak Lake, Virden and Elkhorn. Nest-box \#1131, located five miles northwest of Oak Lake, was occupied by a female Mountain Bluebird and was checked as such by the juniors. Located as we are in mid-continent, we find both Eastern Bluebirds (Sialia sialia) and Mountain Bluebirds (Sialia currucoides) taking advantage of our nest-boxes, of which 1700 were in operation on the above date.

On May 26, I was driving past ilestbox \#1131 (or nest \#1131) and noticed the lid had blown off. When replacing it I verified that a hen Mountain Bluebird was incubating seven eggs, and I was about to drive away when a male bluebird flew into the area. He presented a most unusual spectacle, his breast being a motley of the rusty-red of an Eastern Bluebird and the azure-blue of the Mountain species. To prove that he was the mate of the sitting hen Mountain Bluebird, I flushed her from the nest, and very shortly the odd-appearing little male (he was noticeably smaller than the female) escorted her back to the nest-box, and even flew to the hole to look in at her. After a close scrutiny through my glasses I decided that he must be a hybrid between the Eastern and Mountain species of bluebirds, an important find as I later learned, for there appeared to be no published record of hybridism in the thrush family in the wild in North America. (A report on this find was later made by me at the 85 th annual meeting of the American Ornithologists' Union at Toronto in August, 1967, and a note has been published in the $A u k$ (1968, 85:684). The information that follows supplies details of the study.)

The next morning my wife and I returned to the area and noticed a female Eastern Bluebird defending nest \#1176 from a pair of Tree Swallows. It seemed odd that no mate came to her aid, and later on we had our suspicions aroused when the hybrid male joined this female Eastern near her nest, which was adjacent to nest \#1131 and only 150 yards from it. Later in the day we witnessed a strange bit of by-play: both the hybrid male and his plump Mountain mate flew west along the fenceline till they arrived at the home of the female Eastern bird, where they perched on the fence wire. Very shortly the Eastern hen joined them, and with the female Mountain mate placidly watching the proceedings, the Eastern hen began a series of hops which brought her close to the hybrid male. He in his turn commenced a series of hops to maintain a distance between himself and the amorous hen. When he ran out of wire because of the next fence post, he would hop over the pursuing Eastern bird, which would simply reverse the direction of her hops. After some minutes of this hot pursuit the male abruptly broke off the affair and flew back to his own area, closely followed by his Mountain mate. The nest day, I finally saw the female Eastern bird fly to the telegraph wires above her nest where shortly she was joined by the hybrid. After several false starts copulation took place, proving him to be a polygamist. (I can find only one published record of polygamy in the bluebirds: Harry W. Power (1966. Biology of the Mountain Bluebird in Montana. Condor, 68-351-371 noted one case of polygamy in the Mountain Bluebird in 1963.) By June 2 the female Eastern Bluebird had completed her clutch of five eggs and incubation had begun.

One day earlier, June 1, the Mountain hen hatched out six young; the polygamist proved to be a devoted parent, doing his full share of providing food and keeping the nest tidy. 


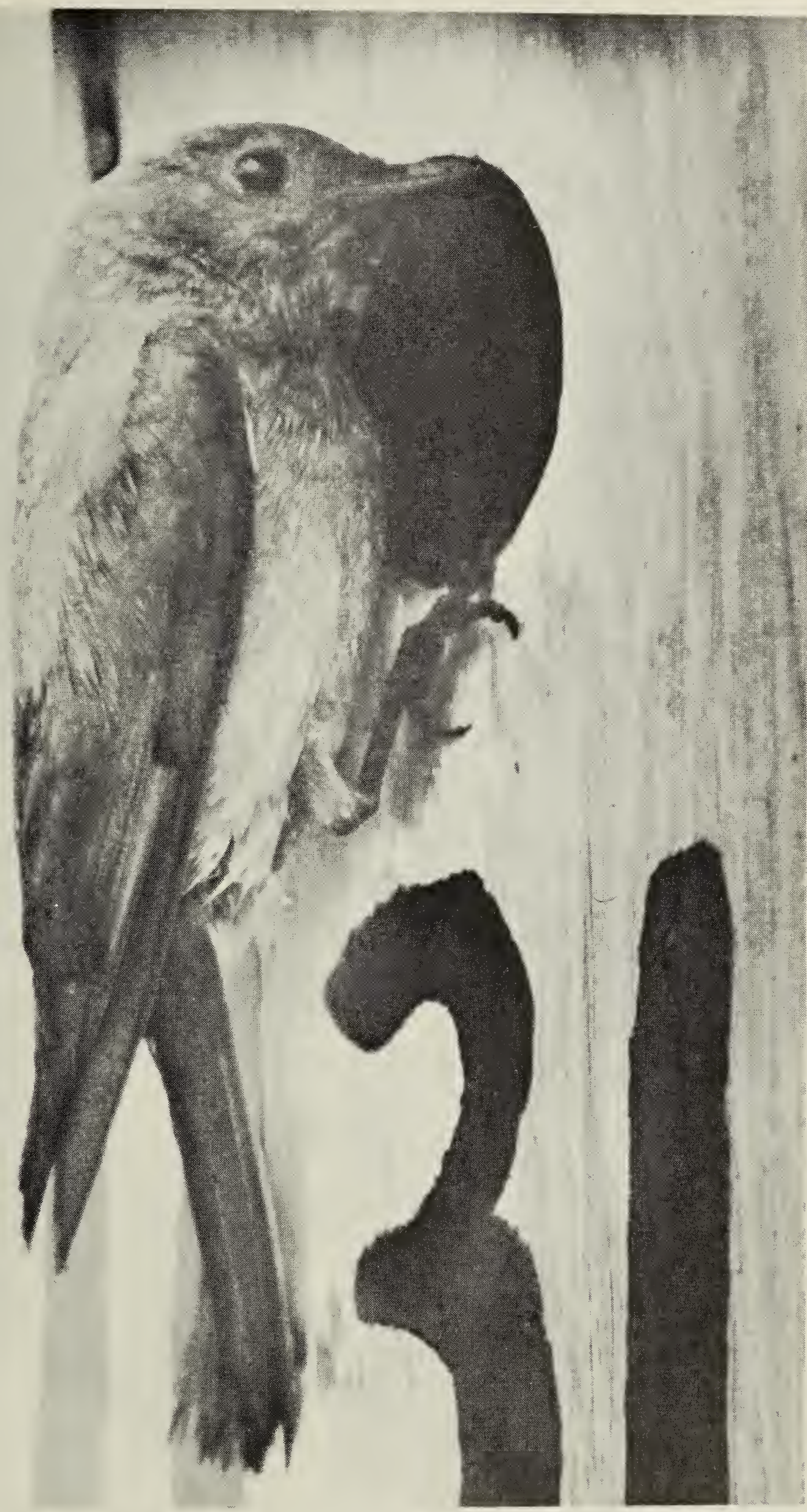

From a color transparency by J. Lane. Courtesy Manitoba Museum of Man and Nature 1ybrid Eastern-Mountain Bluebird male at nest box no. 1131 


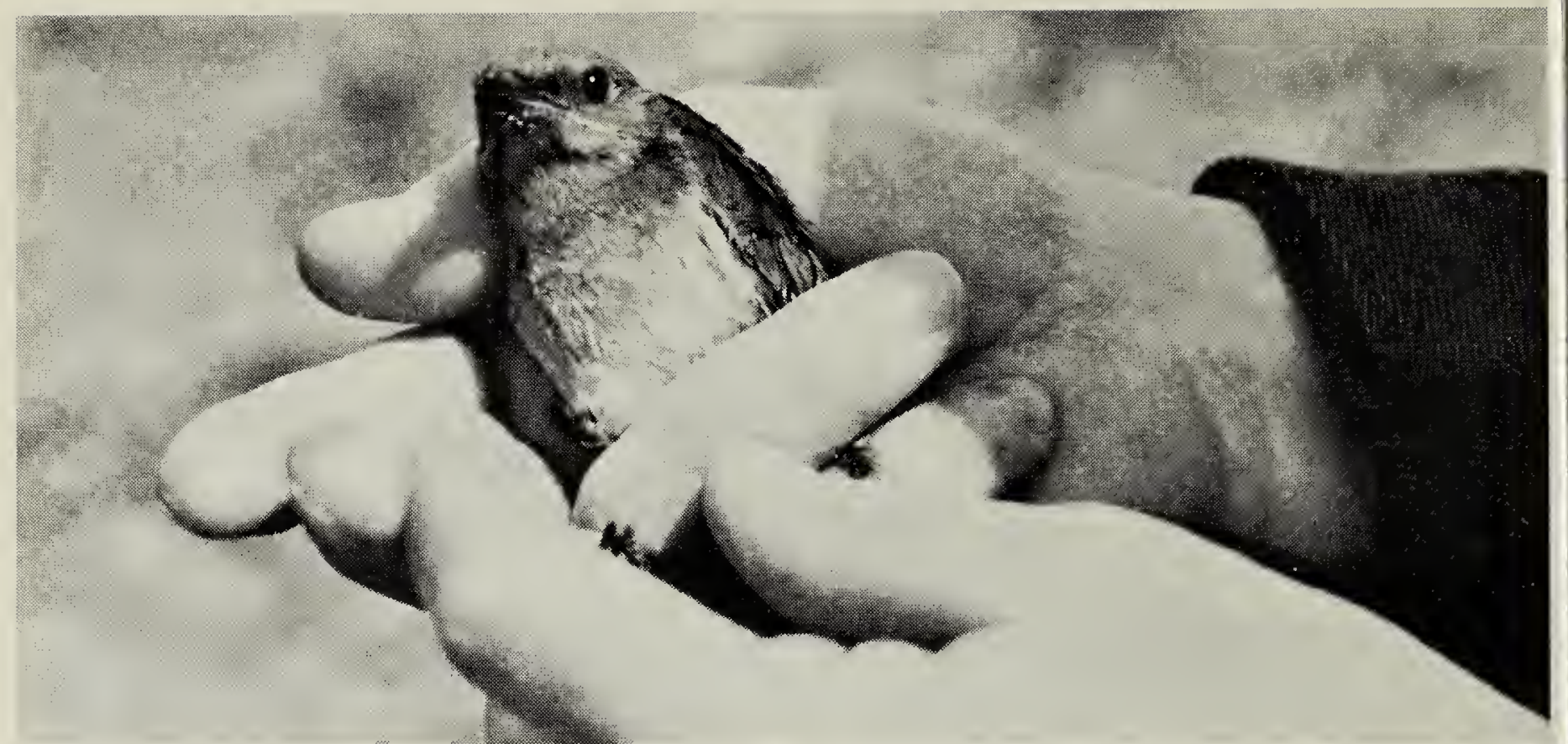

Hybrid male bluebird, June 7, 1967

Even before the young arrived he had displayed a remarkable aggressiveness, and this display reached a new crescendo after the hatching. Any attempt to approach the nest-box resulted in a fierce defense flurry, including much snapping of the bill and a torrent of hoarse, angry "Chupps".

On June 7, with the help of Dr. Robert W. Nero and Mr. W. Harvey Beck, both from the Manitoba Museum of Man and Nature, Winnipeg, the hybrid was captured alive and examined in the hand. The following notes on its plumage were made at that time:

"The most conspicuous feature of the hybrid specimen is the blue and red marking of the breast. In many ways the hybrid seems closer to an Eastern Bluebird, with blue replacing most of the red of the breast. The blue color of the back and wings appears decidedly closer to that of the Eastern Bluebird. The upper throat and breast are largely pale blue, though many of the feathers have reddish tips. Reddish-tipped feathers form a noticeable pattern up the middle of the throat to the base oi the bill. (By June 28, when the bird was collected, these were worn and hence less conspicuous). The lower breast appears as a reddish band, though these feathers are pale blue towards
From a color transparency by W. H. Beck. Courtesy Manitoba Museum of Man and Nature

the base. The red color also runs down the flanks (as in the Eastern species) and again these feathers are blue towards the base - some are almost wholly blue.

"Two additional features may be noted: the outer tail feathers have a narrow white margin on both inner and outer vanes, a characteristic shared with the Eastern Bluebird. Similarly, the metacarpal feathers of the hybrid are chiefly of a whitish color as in the Eastern Bluebird, rather than blue as in the Mountain species."

The hybrid nature of the specimen is also clearly shown by its size, which is intermediate in nearly all respects between the Eastern and Mountain species (Table 1).

It is interesting to note that during the half-hour her mate was held captive, the Mountain hen suspended her feeding chores, spending the time alternately perching on a fence post near her nest, and anxiously flitting about the area.

On June 17 Nero and Beck returned, accompanied by Dr. Roger M. Evans of the Zoology Department, University of Manitoba. Dr. Evans taped the voice of the hybrid, as well as the voices of male Eastern and Mountain bluebirds from nearby nest-boxes. On this same day Dr. Nero took the six hybrid Mountain nestlings to Winni- 
TABLE I. Comparison of hybrid with Eastern and Mountain Bluebirds

\begin{tabular}{l|c|c|c} 
& $\begin{array}{c}\text { Eastern Bluebird } \\
\text { May 25, 1935. } \\
\text { Caddy Lake, Man. } \\
\text { J. D. Soper }\end{array}$ & $\begin{array}{c}\text { Hybrid Bluebird } \\
\text { June 28, 1967 } \\
\text { Brandon West } \\
\text { J. Lane }\end{array}$ & $\begin{array}{c}\text { Mountain Bluebird } \\
\text { April 25, 1949 } \\
\text { Brandon, Man. } \\
\text { R. D. Bird }\end{array}$ \\
\hline Culmen & $11.3 \mathrm{~mm}$. & 11.0 & 10.6 \\
Tarsus & 20.0 & 20.5 & 24.5 \\
Wing (chord) & 100.0 & 104.3 & 112.5 \\
Tail & 62.0 & 66.5 & 70.0 \\
\hline
\end{tabular}

beg, where they were raised for further study. (Four survivors are now with Dr. David C. Krieg of New York for continuing studies of plumages, ehaviour, etc.). When we transferred the young from the nest to a conainer the parents outdid their earlier lemonstrations, darting frenziedly in every direction and maintaining a constant din of vocal protest. As the inal nestling disappeared from view, the Mountain mother began carrying pits of grass to the nest-hole-an nteresting reaction to a disturbing ituation.

The hybrid was destined to become study specimen for the Manitoba Museum of Man and Nature, but we had agreed that he should be spared until we learned if he would also tssist his Eastern mate with her voung, if and when they hatched. I had thought it likely the hybrid and the Mountain hen would renest in pest-box \#1131, but they vanished after the loss of their first brood.

Meanwhile the Eastern hen incupated her eggs for 16 days, then abanloned the nest, the eggs in later tests proving infertile. This bird immeliately mated with a normal male Eastern Bluebird and moved into nestoox \#1131 where a healthy family of ive was raised. Thus it would appear hat the hybrid could fertilize the eggs of the Mountain hen but not those of the Eastern bird.

On June 22, Wayne Miller and I ocated the hybrid male and the Mounain hen moving into nest-box \#781, ocated over two miles west of their bld nest. Since there was no chance ff the hybrid returning to his former area to aid in the raising of a possible family from his Eastern mate's eggs, I arranged for Nero and Beck to make a final trip to the new nest-site on June 28. We collected both the hybrid and his Mountain mate, and found that the hen had already deposited four eggrs in her new nest. We found that the hybrid male weighed seven grams less than the female. Several other features in the hybrid are worth noting: in both posture and silhouette he differed from the two species; when perched on a post he squatted on his heels, giving him a penguin-like appearance; in silhouette he was halfway between the humpty-dumpty shape of the Eastern and the longer, slimmer build of the Mountain species.

$\mathrm{His}$ aggressiveness in nest defense marked him as more Mountain than Eastern, which latter is a much more timid bird. The hybrid's song, both in volume and in clarity of enunciation, was more Eastern than Mountain, the latter uttering a softer, more slurry refrain. Yet Dr. Evans' sonograms show that in pitch the song of the hybrid was actually closer to that of the Mountain Bluebird: measured in averages of frequencies (cycles per second) the hybrid had a figure of 1,612, the male Mountain had 1,643, and the male Eastern a much higher 1,952 .

The author wishes to acknowledge with thanks the aid given by Dr. Robert W. Nero, Mr. W. Harvey Beck, Dr. Roger M. Evans, Mr. Allen Lenny, and three members of the junior club, Wayne Miller, Richard Patterson, and David Randall. And a special salute to his wife for her tireless help. 